\title{
Biochemical Properties of Rhodanese from Almond (Prunus amygdalus) Nuts
}

\author{
Adeola F. Ehigie, Mohammed A. Abdulrasak, Ona L. Ehigie* \\ Department of Biochemistry, College of Health Sciences, Ladoke Akintola University of Tech- \\ nology, Ogbomoso, Nigeria
}

\begin{abstract}
*Correspondence should be addressed to Ona L. Ehigie: lehigie@lautech.edu.ng
Received 18 November 2018; Revised 13 December 2018; Accepted 17 December 2018

(C) 2018 Ehigie et al. Licensee Pan African Journal of Life Sciences. This is an Open Access article distributed under the terms of the Creative commons Attribution License (https://creativecommons.org/licenses/BY/4.0), which permits unrestricted use, distribution, and reproduction in any medium, provided the original work is properly cited.
\end{abstract}

\begin{abstract}
Study of the characteristic pattern of enzymes are useful in the understanding of certain physiological and biochemical processes. Thiosulfate: cyanide sulfurtransferase (rhodanese) is a ubiquitous multifunctional enzyme, that is believed to function in cyanide detoxification. The present study was conducted to determine the activity of rhodanese in almonds (Prunus amygdalus) that belong to the rose family, rosaceae. Rhodanese from the almond nuts was purified by ammonium sulphate precipitation, ion exchange and affinity chromatography. The molecular weight of the enzyme was determined by sodium dodecyl sulphate polyacrylamide gel electrophoresis. The purified rhodanese from the almond nuts had a specific activity of $5.09 \mathrm{RU} / \mathrm{mg}$ with yield of $0.06 \%$. A Km value of $11.14 \mathrm{mM}$ with $\mathrm{Vmax} 0.46 \mathrm{RU} / \mathrm{ml} / \mathrm{min}$ were obtained from $\mathrm{KCN}$ while a $\mathrm{Km}$ value of $13.95 \mathrm{mM}$ with Vmax of $0.48 \mathrm{RU} / \mathrm{ml} / \mathrm{min}$ was obtained from $\mathrm{Na}_{2} \mathrm{~S}_{2} \mathrm{O}_{3}$. The substrate specificity studied indicated that Mercapto-ethanol (MCPE), Ammonium per sulfate $\left(\left(\mathrm{NH}_{4}\right)_{2} \mathrm{~S}_{2} \mathrm{O}_{8}\right.$, Ammonium sulfate $\left(\left(\mathrm{NH}_{4}\right)_{2} \mathrm{SO}_{4}\right.$, Sodium sulfate $\left(\mathrm{Na}_{2} \mathrm{SO}_{4}\right)$ and Sodium metabisulfate $\left(\mathrm{Na}_{2} \mathrm{~S}_{2} \mathrm{O}_{5}\right)$ cannot be substituted for sodium thiosulphate $\left(\mathrm{Na}_{2} \mathrm{~S}_{2} \mathrm{O}_{3}\right)$ as sulphur donor for rhodanese catalytic reaction. The optimum activity of the enzyme was observed at $50 \mathrm{oC}$ and an optimum $\mathrm{pH}$ of 8 . The effect of metals on rhodanese from $\mathrm{Al}-$ mond nut showed that at $1 \mathrm{mM}$ concentration of the metals used did not pronouncedly affect the activity of the enzyme metals except that of $\mathrm{HgCl} 2$ and $\mathrm{MnCl}$. However, the divalent metals including $\mathrm{MnCl}_{2} \mathrm{HgCl}_{2}, \mathrm{CaCl}_{2}$, and $\mathrm{BaCl}_{2}$ inhibited the enzyme at $10 \mathrm{mM}$ concentration. The molecular weight obtained from sodium dodecyl sulphate polyacrylamide gel electrophoresis was estimated to be $35 \mathrm{kDa}$. The study validates the expression of rhodanese activity in almond nut. The characteristic property of rhodanese in the plant may be exploited for bioremediation of cyanide polluted soil.
\end{abstract}

Keywords: Rhodanese, Bioremediation, cyanide, Prunus amygdalus and sulphurtransferase 


\subsection{INTRODUCTION}

Cyanide is a potent cytotoxic agent that destroys the cell by inhibiting cytochrome $\mathrm{c}$ oxidase of the mitochondrial electron transport chain. It could be released to the environment through transportation accidents, pipe failures and tailings dam -related releases [1]. Non-point sources of cyanide released to water include runoff from cyanide-containing anti-caking salts such as sodium ferrocyanide used on roads, migration from landfills, agricultural and atmospheric fallout and washout [2]. In bitter almond, HCN levels $(1062 \pm 148.70 \mathrm{mg} / \mathrm{kg})$ are approximately 40 times higher than levels $(25.20 \pm 8.24 \mathrm{mg} / \mathrm{kg})$ found in sweet almond [3]. This implies that the amount of amygdalin contained in the bitter almond largely exceeds the amount contained in the sweet one. After enzymatic hydrolysis, the amygdalin which is the most important cyanogenic glycoside in Prunus species releases a high level of hydrocyanic acid and a benzaldehyde which is responsible for the bitterness [4]. Knowing that the acute lethal dose of cyanide for mammals is as low as $0.5 \mathrm{mg} \mathrm{CN} / \mathrm{kg}$ of the body weight [5], the acute oral lethal dose of $\mathrm{HCN}$ for humans is reported to be $0.5-3.5 \mathrm{mg} / \mathrm{kg}$ of body weight and the consumption of 50 bitter almonds is deadly for adults [3]. However, for young children, 5-10 almonds are fatal [6].

Almonds (Prunus amygdalus) are prunes that belong to the rose family, the Rosaceae. They were traditionally placed in a sub-family, the Prunoideae (or Amygdaloideae), but sometimes, they are placed in their own family, the Prunaceae (or Amygdalaceae). More recently, it has become apparent that Prunus evolved from the sub-family, Spiraeoideae [7]. The fruit consists of an outer hull and a hard shell with the seed ("hut") inside. Two major types of almonds are grown commercially, which can be categorized as sweet almonds (Prunus amygdalus dulcis) and bitter almonds (Prunus amygdalus amara). The sweet almond is more popular for obvious reasons. Like the olive, the almond provides food and oil and both are produced with little effort from the former. Amygdaline differentiates the bitter almond from the sweet almond. In the presence of water (hydrolysis), amygdaline yields glucose, benzaldehyde and hydrocyanic acid (HCN). The skin of almonds should always be removed before use, as it contains irritating properties. While almonds may cause allergy or intolerance, its cross reactivity with peach allergens (lipid transfer proteins) and tree nut allergens is common. The symptoms range from oral allergy syndrome and contact urticaria to systemic symptoms including anaphylaxis such as urticaria, angio -oedema and gastrointestinal and respiratory symptoms [8]. Although the edible portion of the Prunus amygdalus is its nuts, which are commonly known as almonds and it is a popular, nutritious food [9], the nuts possess various pharmacological properties including lipid lowering [2], immunostimulant [10], anti-oxidant [11], anti-stress [12], Pre-Biotic Potential [13], and cholesterol Lowering Action [14].
Rhodanese (thiosulphate:cyanide sulphurtransferase, EC 2.8.1.1) is a sulphur transferase that catalyses the formation of thiocyanate from free cyanide and a sulphur donor. It functions in the elimination of toxic cyanide and in the biosynthesis of cellular metabolites such as vitamins, enzymes and cofactors that include a step of sulfur transfer [15]. The enzyme is involved in the maintenance of redox homeostasis [16] and bioremediation [17]. While the presence of rhodanese activity has been well studied in some plants, animals and microorganisms, its presence has not been studied in almond seeds. This study was therefore designed to investigate the presence of rhodanese and its activity in almond nut and to compare its physicochemical properties with rhodanese from other sources.

\subsection{METHODOLOGY}

Fresh almond fruits were collected from Ladoke Akintola University of Technology (LAUTECH), Ogbomoso, Nigeria. They were identified at the Department of Biology, Ladoke Akintola University of Technology, Ogbomoso, Nigeria. The fresh almond fruits were washed and nuts were removed.

\subsection{Enzyme Extraction and Isolation}

One hundred grams $(100 \mathrm{~g})$ of the crushed almond nuts were homogenized in three volumes of $100 \mathrm{mM}$ phosphate buffer, $\mathrm{pH} 6.5$ containing $10 \mathrm{mM}$ sodium thiosulphate with a Warring Blender. The homogenate was filtered through a double layer of cheese cloth and then centrifuged at $4000 \mathrm{rpm}$ at $10^{\circ} \mathrm{C}$ for 15 min using Centurion cold centrifuge (R-1880). The pellets were discarded and an aliquot of the supernatant was then assayed for rhodanese activity and protein concentration.

\subsection{Ammonium Sulphate Precipitation}

One hundred millilitres $(100 \mathrm{ml})$ of the supernatant of the crude enzyme was brought to $80 \%$ ammonium sulphate saturation by slow addition and stirring of $51.6 \mathrm{~g}$ solid ammonium sulphate. This was done for $1 \mathrm{~h}$ with occasional stirring until all the salt had dissolved completely in the supernatant. The mixture was left for $12 \mathrm{~h}$ at $4^{\circ} \mathrm{C}$. The resulting precipitate was collected by centrifugation at $4,000 \mathrm{rpm}$ for $30 \mathrm{~min}$ and immediately dialyzed against several changes of a $0.1 \mathrm{M}$ solution of phosphate buffer ( $\mathrm{pH} 7.2)$ at $4^{\circ} \mathrm{C}$ for 8 hours using a dialysis bag. The dialysate was centrifuged (to remove insoluble materials) at $4,000 \mathrm{rpm}$ for $15 \mathrm{~min}$ and the supernatant was assayed for rhodanese activity and protein concentration.

\subsection{Enzyme Assay}

Rhodanese activity was measured according to the previously described method [18]. The reaction mixture consists of 0.25 $\mathrm{ml}$ of $50 \mathrm{mM}$ borate buffer (pH 9.4), $0.1 \mathrm{ml}$ of $250 \mathrm{mM} \mathrm{KCN}$, $0.1 \mathrm{ml}$ of $250 \mathrm{mM} \mathrm{Na}_{2} \mathrm{~S}_{2} \mathrm{O}_{3}$ and $0.1 \mathrm{ml}$ of the enzyme solution in a total volume of $0.55 \mathrm{ml}$. The mixture was incubated at $37^{\circ}$ $\mathrm{C}$ for $1 \mathrm{~min}$ and the reaction was stopped by adding $0.25 \mathrm{ml}$ of 
$15 \%$ formaldehyde, followed by the addition of $0.75 \mathrm{ml}$ of Sorbo reagent. The absorbance was taken at $460 \mathrm{~nm}$.

\subsection{Protein Determination}

Protein concentration was determined by the method of Bradford [19] using Bovine Serum Albumin (BSA) as the standard where the protein absorbance was interpolated from a standard protein curve. The reaction mixture consists of $10 \mu \mathrm{l}$ of the enzyme solution and $1.0 \mathrm{ml}$ of Bradford reagent. The absorbance was taken at $595 \mathrm{~nm}$.

\subsection{Ion-Exchange Chromatography on CM-Sephadex C-50} CM-Sephadex C-50 cation exchanger was pretreated by boiling $5 \mathrm{~g}$ of the resin in distilled water for $1 \mathrm{~h}$. This was followed by the addition of $100 \mathrm{ml} 0.1 \mathrm{M} \mathrm{HCl}$ for $30 \mathrm{~min}$ after which the acid was decanted and the resin was washed with distilled water several times to ensure the total removal of the acid. Thereafter, $100 \mathrm{ml}$ of $0.1 \mathrm{M} \mathrm{NaOH}$ was added to the resin, which was decanted after $30 \mathrm{~min}$, followed by the thorough rinsing of the resin with distilled water to remove all traces of the base. The resin was then equilibrated with $0.1 \mathrm{M}$ phosphate buffer $(\mathrm{pH} 7.6)$ before it was packed into a $2.5 \times 40 \mathrm{~cm}$ column. Six millilitres $(6 \mathrm{ml})$ of the enzyme solution from the preceding step was then applied on the column. The column was washed with $0.1 \mathrm{M}$ phosphate buffer $(\mathrm{pH}$ 7.6) to remove unbound protein, followed by a step-wise elution with $0.5 \mathrm{M}$ $\mathrm{NaCl}$ and $1.0 \mathrm{M} \mathrm{NaCl}$ in the same buffer. Fractions of $4 \mathrm{ml}$ were collected from the column at a rate of $48 \mathrm{ml}$ per $\mathrm{h}$. The active fractions from the column were pooled and dialyzed against $50 \%$ glycerol in $0.1 \mathrm{M}$ phosphate buffer, $\mathrm{pH}$ 7.6. The dialyzed fraction was assayed for rhodanese activity and protein determination using Bradford reagent, the active fractions pooled were stored in a refrigerator.

\subsection{Affinity Chromatography on Reactive Blue-2 Agarose}

Fifteen millilitres of Reactive Blue-2 Agarose resin was packed into a $1.5 \times 10 \mathrm{~cm}$ glass column and equilibrated with $0.05 \mathrm{M}$ citrate buffer ( $\mathrm{pH}$ 5.0). Three millilitres of enzyme solution from the preceding step was then layered on the column and washed with the buffer to remove unbound protein, followed by a step-wise elution with $1.0 \mathrm{M} \mathrm{NaCl}$ solution in the same buffer. Fractions of $2 \mathrm{ml}$ were collected from the column at a rate of $12 \mathrm{ml}$ per $\mathrm{h}$. The active fractions from the column were pooled and dialyzed against $100 \mathrm{ml} \mathrm{50 \%} \mathrm{glycerol} \mathrm{in}$ $0.1 \mathrm{M}$ phosphate buffer, $\mathrm{pH}$ 7.5. The dialyzed fraction was assayed for rhodanese activity and protein.

\subsection{Determination of Native Molecular Weight}

The native molecular weight was determined on a Sephadex G $-100(2.5 \times 90 \mathrm{~cm})$. The standard proteins were bovine serum albumin (Mr 66000; $5 \mathrm{mg} / \mathrm{ml}$ ), ovalbumin ( $\mathrm{Mr} \mathrm{45000;5} \mathrm{mg/}$ $\mathrm{ml}$ ) and chymotrypsinogen-a (Mr 25,000; 5mg/ml). Total sample volume of each of the protein markers applied to the col- umn was $5 \mathrm{ml}$. The proteins were eluted with phosphate buffered saline $\mathrm{pH}$ 7.2. Fractions of $5 \mathrm{ml}$ were collected and monitored by measuring absorbance at $280 \mathrm{~nm}$ for the protein. The void volume ( $\mathrm{V} 0)$ of the column was determined by the elution volume $(\mathrm{Ve})$ of Blue dextran $(2 \mathrm{mg} / \mathrm{ml})$. A $5 \mathrm{ml}$ aliquot of the enzyme solution was then applied to the same column and the elution volume of the rhodanese was determined.

\subsection{Sodium Dodecyl Polyacrylamide Gel Electrophoresis (SDS-PAGE)}

Sodium dodecyl sulphate polyacrylamide gel electrophoresis (SDS-PAGE) was carried out according to the method of Weber and Osborn [20] to determine the subunit molecular weight of the enzyme on a $10 \%$ slab gel apparatus with a notched glass plate. Gels of $1.5 \mathrm{~mm}$ thickness were prepared by using perplex spacers of same size. A mixture of the enzyme sample and sample buffer containing SDS (10\%), bromophenol blue, $\beta$ -mecaptoethanol and glycerol was prepared in a concentration of $1: 1$, and was then heated in boiling water bath for $3 \mathrm{~min}$ and then allowed to cool. Fifteen microlitre of the mixture along with the same volume of protein standards were applied to different wells on the slab and electrophoresed at a constant voltage of 70 volts to allow stacking of the proteins. The standard proteins that were used for the calibration of the gel were bovine serum albumin $(66,000 \mathrm{Da})$, ovalbumin $(45,000 \mathrm{Da})$, trypsin inhibitor $(20,100 \mathrm{Da})$ and lysozyme (14,300 Da), which had also been denatured by mixing with SDS and heating for $3 \mathrm{~min}$. After stacking was achieved, the voltage was increased to 100 volts to allow separation of the proteins in the resolving gel. After electrophoresis, the gels were stained in $0.04 \%$ Coomasie brilliant blue R-250 in 3.5\% perchloric acid solution for $1 \mathrm{~h}$, followed by destaining in a solution containing $7.5 \%$ acetic acid to increase the sensitivity of detection. After destaining, the lengths of the gels as well as the distance of migration by the different protein bands were measured.

\subsection{Determination of Kinetic Parameters}

The kinetic parameters ( $\mathrm{Km}$ and $\mathrm{Vmax}$ ) of the enzyme were determined. The $\mathrm{Km}$ and Vmax of sodium thiosulphate and potassium cyanide were determined by varying concentrations of sodium thiosuphate and potassium cyanide between $10 \mathrm{mM}$ and $50 \mathrm{mM}$ at a fixed concentration of $25 \mathrm{mM}$ potassium cyanide and sodium thiosuphate respectively in $50 \mathrm{mM}$ buffer $\mathrm{pH}$ 9.4. The kinetic parameters were determined from the double reciprocal plot.

\subsection{Effect of $\mathrm{pH}$ on the Rhodanese Activity}

The effect of $\mathrm{pH}$ was studied by assaying the enzyme using different buffers: $0.1 \mathrm{M}$ citrate buffer ( $\mathrm{pH} 3.0-6.0$ ); $0.1 \mathrm{M}$ phosphate buffer $(\mathrm{pH} 7.0-8.0)$ and borate buffer $(\mathrm{pH} 9.0-10.0)$. The reaction mixture of $1.0 \mathrm{~mL}$ contained $0.25 \mathrm{~mL}$ of buffer and other reagents as contained in the normal rhodanase assay protocol $[20,21]$. 


\subsection{Effect of Temperature on the Rhodanese Activity}

The enzyme was assayed at temperatures between $30^{\circ} \mathrm{C}$ and $100^{\circ} \mathrm{C}$ to investigate the effect of temperature on the activity of the enzyme and to determine the optimum temperature of the enzyme activity. The assay mixture was first incubated at the indicated temperature for $10 \mathrm{~min}$ before initiating reaction by the addition of an aliquot of the enzyme which had been equilibrated at the same temperature. The rhodanese activity was assayed routinely as previously described $[20,21]$.

\subsection{Effect of Salts on the Enzyme Activity}

The salts tested were $\mathrm{NaCl}, \mathrm{KCl}, \mathrm{BaCl}_{2}, \mathrm{HgCl}_{2}$ and $\mathrm{MnCl}_{2}$ at $0.001 \mathrm{mM}$, and $0.01 \mathrm{mM}$ from stock solutions of $0.1 \mathrm{mM}$ in a typical rhodanase assay mixture. The metallic chlorides were dissolved in distilled water. The reaction mixture without the salts was taken as control with $100 \%$ activity [23].

\subsection{Substrate Specificity}

The substrate specificity of the enzyme was investigated by testing its activity towards structurally similar compounds. The compounds include Mercapto-ethanol (MCPE), Ammonium per sulfate $\left.\left(\mathrm{NH}_{4}\right)_{2} \mathrm{~S}_{2} \mathrm{O}_{8}\right)$, Ammonium sulfate $\left.\left(\mathrm{NH}_{4}\right)_{2} \mathrm{SO}_{4}\right)$, Sodium sulfite $\left(\mathrm{Na}_{2} \mathrm{SO}_{4}\right)$, Sodium metabisulfate $\left(\mathrm{Na}_{2} \mathrm{~S}_{2} \mathrm{O}_{5}\right)$. The solutions of the compound $(250 \mathrm{mM})$ were prepared in $50 \mathrm{mM}$ borate buffer, $\mathrm{pH} 9.4$ and assayed as described above.

\subsection{RESULTS}

\subsection{Purification}

The result of the purification protocol for Almond Rhodanese showed a specific activity $5.09 \mathrm{RU} / \mathrm{mg}$ with yield of $0.06 \%$. The purification procedure is summarized in Table 1. Figure 1 and 2 shows elution profile of Ion-exchange chromatography on CM-Sephadex C-50 and Reactive Blue-2 Agarose Affinity Chromatography respectively.

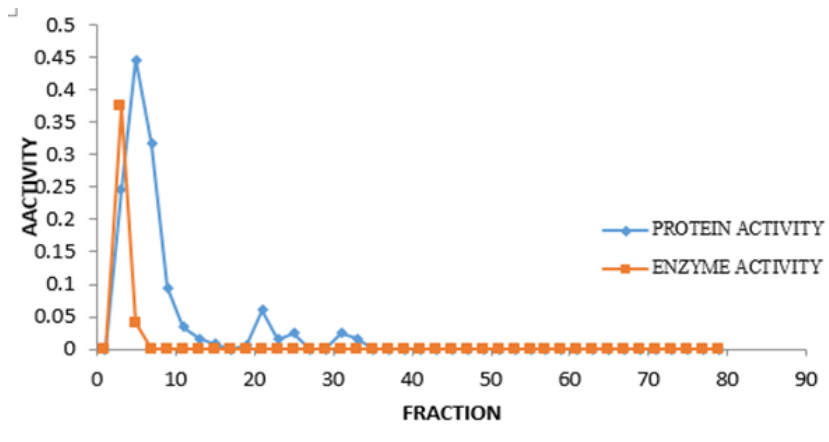

Figure 1: Elution profile on CM-Sephadex-C-50 ion exchange chromatography for Rhodanese from almond nut.

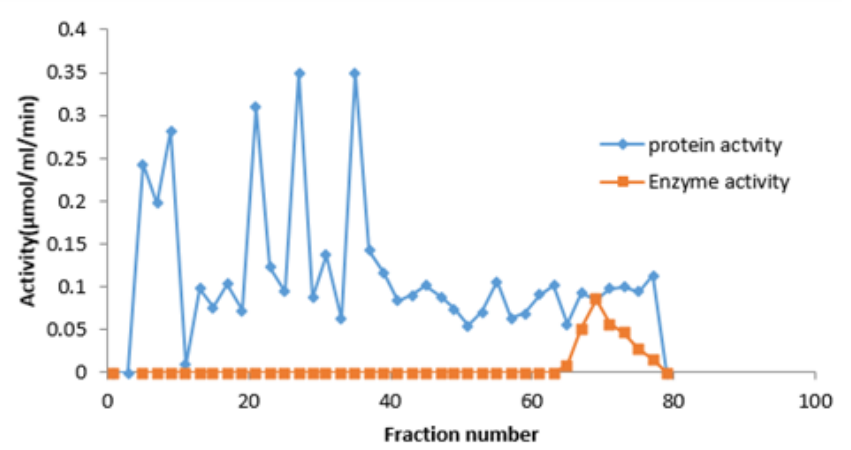

Figure 2: Elution profile on Blue-2 Agarose Affinity Chromatography for Rhodanese from almond nut.

Table 1: The purification profile of rhodanese from almond nut

\begin{tabular}{llllll}
\hline & $\begin{array}{l}\text { Total } \\
\text { Protein } \\
\text { (mg) }\end{array}$ & $\begin{array}{l}\text { Total } \\
\text { Activity } \\
\text { (U) }\end{array}$ & $\begin{array}{l}\text { Specific } \\
\text { Activity } \\
\text { (u/mg) }\end{array}$ & $\begin{array}{l}\text { Yield } \\
\text { \% }\end{array}$ & $\begin{array}{l}\text { Purifi- } \\
\text { cation } \\
\text { Fold }\end{array}$ \\
\hline Crude Enzyme & 190.88 & 478.69 & 2.51 & 1.00 & 1.00 \\
$\begin{array}{l}80 \%(\mathrm{NH} 4)_{2} \mathrm{SO} 4 \\
\text { Precipitation }\end{array}$ & 29.7 & 85.77 & 2.89 & 0.18 & 1.15 \\
$\begin{array}{l}\text { CM-Sephadex C } \\
\text {-50 Ion Ex- } \\
\text { change Chroma- } \\
\text { tography }\end{array}$ & 11.32 & 54.24 & 4.79 & 0.11 & 1.91 \\
$\begin{array}{l}\text { Reactive Blue-2 } \\
\text { Agarose Affinity } \\
\text { Chromatography }\end{array}$ & 5.26 & 26.79 & 5.09 & 0.06 & 2.03 \\
\hline
\end{tabular}

\subsection{Kinetic Parameter}

Rhodanese followed Michaelis-Menten kinetics with a $\mathrm{K}_{\mathrm{m}}$ for sodium thiosulphate $\left(\mathrm{Na}_{2} \mathrm{~S}_{2} \mathrm{O}_{3}\right)$ of $13.95 \mathrm{mM}$ with $\mathrm{V}_{\max }$ of 0.48 $\mathrm{RU} / \mathrm{ml} / \mathrm{min}$ estimated from a double reciprocal plot (Table 2 and Figure 3). The $\mathrm{K}_{\mathrm{m}}$ for potassium cyanide $(\mathrm{KCN})$ of $11.14 \mathrm{mM}$ with $\mathrm{V}_{\max } 0.46 \mathrm{RU} / \mathrm{ml} / \mathrm{min}$ estimated from double reciprocal plot (Table 2 and Figure 4).

Table 2: The Kinetic Values of the Potassium cyanide and Potassium cyanide substrates.

\begin{tabular}{lll}
\hline Substrate & $\mathbf{K}_{\mathbf{m}}$ & $\mathbf{V}_{\max }$ \\
\hline Potassium cyanide & 11.14 & 0.46 \\
Sodium thiosulphate & 13.95 & 0.48 \\
\hline
\end{tabular}

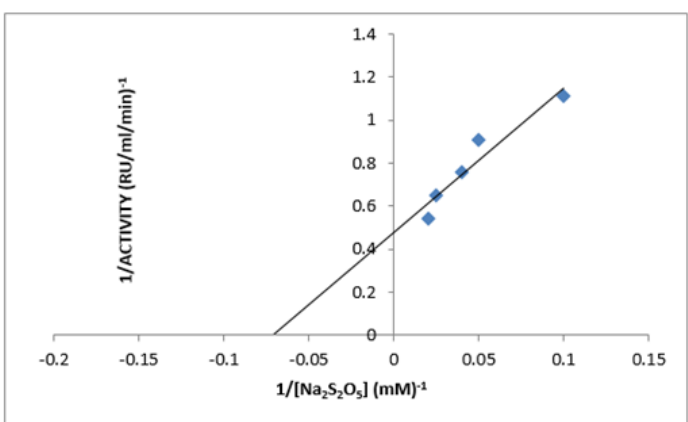

Figure 3: Lineweaver-Burk Plot for Varying Concentration of Sodium Thiosulphate Lineweaver-Burk plot of $1 / \mathrm{V}$ against $1 /[\mathrm{S}]$ at varying concentrations of $\mathrm{Na}_{2} \mathrm{~S}_{2} \mathrm{O}_{3}$ between $10 \mathrm{mM}$ and $50 \mathrm{mM}$ and a constant concentration of $\mathrm{KCN}$ at $25 \mathrm{mM}$. 


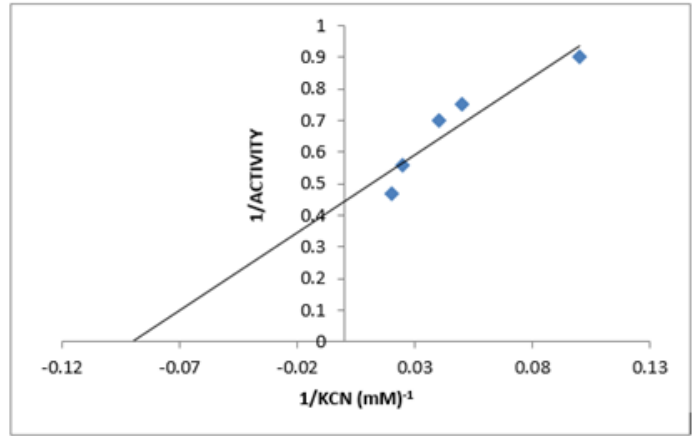

Figure 4: Lineweaver-Burk Plot for Varying Concentration of Potassium Cyanide Lineweaver-Burk plot of $1 / \mathrm{V}$ against $1 /[\mathrm{S}]$ at varying concentrations of $\mathrm{KCN}$ between $10 \mathrm{mM}$ and $50 \mathrm{mM}$ and a constant concentration of $\mathrm{Na}_{2} \mathrm{~S}_{2} \mathrm{O}_{3}$ at $25 \mathrm{mM}$.

\subsection{Effect of $\mathrm{pH}$ and Temperature}

The effect of $\mathrm{pH}$ on the enzyme was determined using assay buffer ranging from 3 to 11 . The $\mathrm{pH}$ assay was done to determine the optimum $\mathrm{pH}$ of enzyme activity. There was an increase in the enzyme activity between $\mathrm{pH} 8.0$ and 9.0. An optimum $\mathrm{pH}$ of 8.0 was observed (figure 5). The effect of temperature on the enzyme was determined by assaying at different temperatures between $30^{\circ} \mathrm{C}$ to $100^{\circ} \mathrm{C}$ to investigate the effect of temperature on the enzyme activity. The optimum activity was observed at $50^{\circ} \mathrm{C}$ (Figure 6).

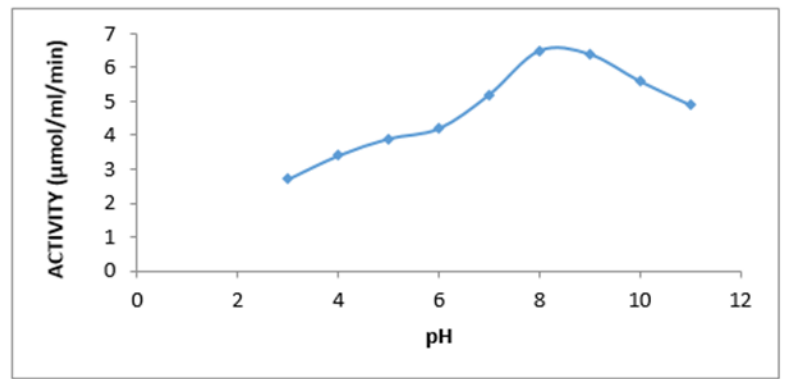

Figure 5: Effect of $\mathrm{pH}$ on Rhodanese Activity from Almond

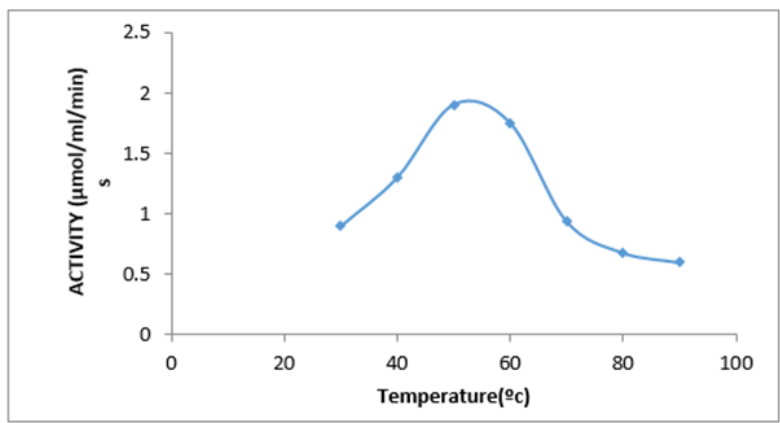

Figure 6: Effect of Temperature $\left({ }^{\circ} \mathrm{C}\right)$ on Rhodanese Activity from Almond nut

\subsection{Substrate Specificity}

Substrate specificity of Rhodanese was investigated by testing its activity towards structurally related sulfur compounds in a typical Rhodanese assay mixture. The activity was expressed as a percentage activity of the enzyme using sodium thiosulphate as the control (Table 3).
Table 3: Percentage Substrate Specificity of each Sulphur Compound

\begin{tabular}{lc}
\hline Substrate & \% Activity \\
\hline Sodium thiosulphate & 100 \\
Sodium Metabisulphite & 24.99 \\
Ammonium persulphate & 31.62 \\
Mecaptoethanol & 27.7 \\
\hline
\end{tabular}

\section{Effect of Metals}

The effect of metal ions $\left(\mathrm{NaCl}, \mathrm{KCl}, \mathrm{HgCl}_{2}, \mathrm{BaCl}_{2}, \mathrm{MnCl}_{2}\right)$ at concentrations of $1 \mathrm{mM}$ and $10 \mathrm{mM}$ using their chloride salts was studied. The enzyme activity was inhibited by $\mathrm{HgCl} 2$ and $\mathrm{BaCl}_{2}$ in a concentration dependent manner while $\mathrm{KCl}, \mathrm{NaCl}$ and $\mathrm{MnCl}_{2}$ had no pronounce effect on the enzyme as shown in the Table 4.

Table 4: Effect of Metals on Rhodanese from almond

\begin{tabular}{ccc}
\hline $\begin{array}{c}\text { Chloride } \\
\text { Salt }\end{array}$ & $\begin{array}{c}\text { \% Residual Activity } \\
(\mathbf{1} \text { mM) }\end{array}$ & $\begin{array}{c}\text { \% Residual Activity } \\
\text { (10 } \mathbf{~ m M})\end{array}$ \\
\hline $\mathrm{HgCl}_{2}$ & 75 & 63 \\
$\mathrm{KCl}$ & 98 & 94 \\
$\mathrm{CaCl}_{2}$ & 87 & 67 \\
$\mathrm{NaCl}$ & 97 & 92 \\
$\mathrm{BaCl}_{2}$ & 80 & 60 \\
$\mathrm{MnCl}_{2}$ & 78 & 65 \\
\hline
\end{tabular}

\subsection{Molecular Weights on SDS PAGE}

Figures 7 and 8 show the electrophoretogram and calibration curve respectively, obtained for the sodium dodecyl sulphate polyacrylamide gel electrophoresis (SDS- PAGE). The molecular weight estimated from the SDS-PAGE was estimated to be $35 \mathrm{KDa}$.

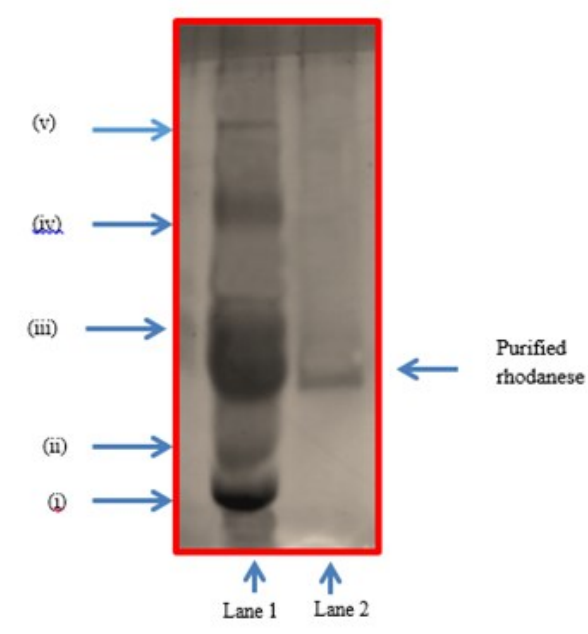

Figure 7: Photograph of SDS-PAGE of almond nut rhodanese.

Lane 1=Standard Proteins; The standard molecular weight markers are: $i=L y s o z y m e$ $(14.3 \mathrm{kDa})$, ii=Trypsinogen $(24.0 \mathrm{kDa})$, iii=Pepsinogen (34.5), iv=Ovalbumin (45.0 kDa), and $\mathrm{v}=\mathrm{BSA}(66.0 \mathrm{kDa})$. Lane $2=$ almond nut rhodanese 


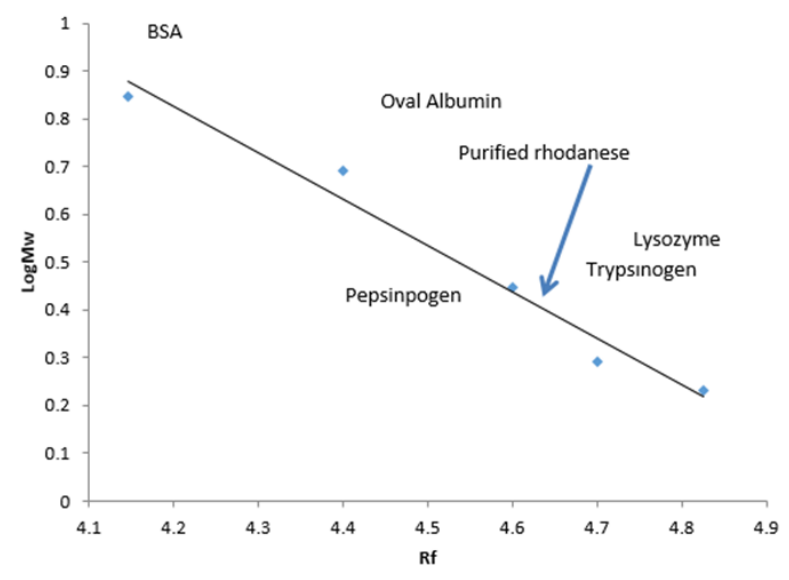

Figure 8: $\log M_{w}$ versus $R_{f}$ for the estimation of Molecular Weight of Proteins

\subsection{DISCUSSION}

Cyanides generally are compounds of varying degrees of chemical complexity. They contain a CN moiety, to which humans are exposed in gas, liquid and solid form from a broad range of natural and anthropogenic sources [24]. Cyanogenic glycosides are glycosides containing cyanide moiety. Cyanogenic glycosides are contained in several edible plants, whose concentrations can vary widely as a result of both developmental (endogenous) and ecological (exogenous) comprising of genetic and environmental factors, location, season and soil types $[24,25]$. Plants can readily take up cyanide and metallocyanides when present around their root zone [27]. While Anosike and Ugochukwu [28] showed strict correlation between cyanide content and rhodanese levels in six different cassava varieties, the presence of rhodanese activity has been studied in cassava leaf [29], cabbage [30], and ginger and snake tomatoes plants $[17,31]$. There is no doubt about the existence of rhodanese in plants as molecular and biochemical studies have proven their existence in plants. At the close of the 20th century Saito and Haltzfeld [32] confirmed the existence of rhodanese in plants by characterizing for the first time in plants two cDNAs encoding rhodanese isoforms in Arabidopsis thaliana AtRDHI and AtRDH2.

In this study, the enzyme had a specific activity of 5.09 RU per $\mathrm{mg}$ of protein and $0.06 \%$ recovery. A purification fold of 12.5 fold and specific activity of 8.81 mole was obtained for sheep liver rhodanese [33]. Jack et al., [34] purified rhodanese from marine fish (Lutjanus goreensis) liver to 11.4 fold and a specific activity of $19.7 \mu \mathrm{Mmin}-1 \mathrm{mg}-1$ enzyme protein. A yield of 7.8 was obtained in tapioca leave [29] and a specific activity of 5.4 RU per mg of protein. Our previous study [17] also reported a purification fold of 1.02 and specific activity of $0.47 \mathrm{RU} /$ $\mathrm{mg}$ for ginger (Zinginber officinale) rhizome.

Rhodanese catalysis is a non-sequential double displacement mechanism as previously reported [21, 22] for bovine liver rhodanese. Researchers on rhodanese have reported various affinities between the substrates. The apparent $\mathrm{Km}$ values of almond nut for $\mathrm{KCN}$ and $\mathrm{Na} 2 \mathrm{~S} 2 \mathrm{O} 3$ were 11.14 and $13.95 \mathrm{mM}$ respectively in this study. This shows that the enzyme has a higher affinity for potassium cyanide compared to sodium thiosulphate. Lower Km value is an indication of strong affinity of the enzyme for the substrate and high efficiency of the catalysis of the detoxification reaction. It was reported that the $\mathrm{P}$. brazzeana root rhodanese binds to $\mathrm{Na} 2 \mathrm{~S} 2 \mathrm{O} 3$ and (NH4)2S2O 8 with similar affinity and to $\mathrm{Na} 2 \mathrm{~S} 2 \mathrm{O} 5$ with less affinity when all three sulphur donors are compared. Sodium thiosulphate (Na2S2O3) has been reported to be highly specific for rhodanese [22,35] although the enzyme can utilize other sulphur donors as substrate [36]. The $\mathrm{Km}$ of rhodanese from $T$. cucumerina mesocarp and seed for sodium thiosulphate $(\mathrm{Na} 2 \mathrm{~S} 2 \mathrm{O} 3)$ and potassium cyanide $(\mathrm{KCN})$ were 12.5 and 10 $\mathrm{mM}$, respectively [36]. Rhodanese in the cytosolic fraction of the fruit bat liver with values $19.15 \mathrm{mM}$ and $13.36 \mathrm{mM}$ for sodium thiosulphate $(\mathrm{Na} 2 \mathrm{~S} 2 \mathrm{O} 3)$ and potassium cyanide $(\mathrm{KCN})$ respectively [18] and Rhodanese in hepatopancreas of Limicolaria flammea with values $19.15 \mathrm{mM}$ and $13.36 \mathrm{mM}$ for sodium thiosulphate $(\mathrm{Na} 2 \mathrm{~S} 2 \mathrm{O} 3)$ and potassium cyanide $(\mathrm{KCN})$ respectively [37]. However, some other researchers reported a higher affinity for sodium thiosulphate as compared to potassium cyanide. The $\mathrm{Km}$ values of $52.63 \mathrm{mM}$ and $90 \mathrm{mM}$ for sodium thiosulphate $(\mathrm{Na} 2 \mathrm{~S} 2 \mathrm{O} 3)$ and potassium cyanide $(\mathrm{KCN})$ respectively were reported for the rhodanese enzyme from ginger (Zinginber officinale) rhizome [17]. On the other hand, Boey et al., reported $15 \mathrm{mM}$ and $66 \mathrm{mM}$ for sodium thiosulphate (Na2S2O3) and potassium cyanide $(\mathrm{KCN})$ respectively for rhodanese from tapioca leaf [38] while Jack et al., reported $5.88 \mathrm{mM}$ and $11.11 \mathrm{mM}$ for sodium thiosulphate $(\mathrm{Na} 2 \mathrm{~S} 2 \mathrm{O} 3)$ and potassium cyanide $(\mathrm{KCN})$ respectively for the fish liver Rhodanese [34].

The substrate specificity study of rhodanese isolated from the almond nut has preference for sodium thiosulphate but to a far lesser extent it can also use other sulphur compounds such as ammonium persulphate, sodium metabissulphite and 3mercaptoethanol for its catalytic activities. This is in line with the previous studies $[39,40]$ that reported the use of varying sulphur compounds from a sulphane pool by rhodanese. The specificity of rhodanese for sulphur from thiosulphate source. The study of the ability of different thiosulphates to substitute thiosulphate in rhodanese reaction was first reported in 1953 [22].

The effect of metals on rhodanese from Almond nut showed that at $1 \mathrm{mM}$ concentration of the metals used did not pronouncedly affect the activity of the enzyme except that of $\mathrm{HgCl} 2$ and $\mathrm{MnCl} 2$. However at $10 \mathrm{mM}$ concentration, the divalent metals - $\mathrm{MnCl} 2, \mathrm{HgCl} 2, \mathrm{CaCl} 2$, and $\mathrm{BaCl} 2$ - inhibited the enzyme. It was reported that rhodanese from bat liver was inhibited by $\mathrm{Ba} 2+[18]$ while $\mathrm{Zn} 2+$ inhibited African catfis 
(Clarias gariepinus) liver rhodanese [41]. Mercury and zinc ions have been reported as potent inhibitors of rhodanese active site through their interactions with side chain residues $[40,18]$.

The rhodanese from Almond nut showed maximum activity at $\mathrm{pH} 8.0$ which is consistent with the values from other plants including the snake tomato seed rhodanese [43]. The optimum $\mathrm{pH}$ of Pentadiplandra brazzeana (Baill) root rhodanese was also found to be 8.0 [34]. Different optimum $\mathrm{pH}$ values in the range of 7.0-11.0 have also been reported in African catfish liver [41], ginger rhodanese [17], tapioca leaf [29] marine fish [34] and sheep liver rhodanese [33]. An optimum temperature of $50^{\circ} \mathrm{C}$ was obtained for rhodanese isolated from Almond nut inthis study. Rhodanese isolated from both Seed and mesocarp of Trichosanthes cucumerina was reported to have identical optimum temperature of $50^{\circ} \mathrm{C}$ [43]. Similar optimum temperatures were obtained in bovine liver [21], mudskipper liver [39] and ginger [17]. An optimum temperature ranging between 35 and $55^{\circ} \mathrm{C}$ for rhodanese enzyme in different Trichoderma strains [44]. The high temperature might be as a result of adaptation to harsh environmental condition. On the contrary, while the rhodanese in the cytosolic fraction of fruit Bat liver was reported to have an optimal temperature of $35^{\circ} \mathrm{C}$ [18], an optimum temperature of $40^{\circ} \mathrm{C}$ for rhodanese was reported from the liver of the catfish in Asejire Lake [41]. The subunit molecular weight obtained from Sodium dodecyl sulphate polyacylamide gel electrophoresis (SDS-PAGE) was estimated to be $35 \mathrm{kDa}$ almond nuts. The estimated value is relatively similar and in agreement with the range of $31 \mathrm{kDa}-37 \mathrm{KDa}$ as reported by most other researchers working on rhodanese. A molecular weight of 37,000 Dalton was reported for bovine liver rhodanese [21], the same value was also reported for human liver rhodanese [45] which is a monomeric protein. A molecular weight of 34,800 Dalton and the SDS-PAGE of 34,000 Dalton was reported for mouse liver rhodanese, suggesting that the enzyme is a monomeric globular protein [23].

In conclusion, the study demonstrates the biochemical properties of the rhodanese in Almond nut which compares very well with the reports of the enzyme from other sources. The plant may perform the vital role of cyanide detoxification and possibly be exploited in remediation of polluted soil due to human activities.

\section{Conflict of interest}

The authors declare that there is no conflict of interest

\section{References}

1. Mudder TI and Botz M, 'Mudder TI, Botz M. A global perspective of cyanide. A background paper of the UNEP/ICME Industry Codes of Practice Workshop: Cyanide Management Paris, 26-27 May 2000. (http:// www.mineralresourcesforum.org/initiatives/cyanide/docs/ mudder.pdf).',2000.[Online].Available:http://www.mineralresources forum.org/initiatives/cyanide/docs/mudder.pdf.

2. Siller H and Winter J, 'Siller H, Winter J (1998). Degradation of cyanide in agroindustrial or industrial wastewater in an acidification reactor or in a singlestep methane reactor by bacteria enriched from soil and peels of cassava. Applied Microbiology and Biotechnology. 1998; 50:384-389.

3. Chaouali N, Gana I, Dorra A, Khelifi F, Nouioui AM, Asri W, et al.
Potential Toxic Levels of Cyanide in Almonds (Prunus amygdalus), Apricot Kernels (Prunus armeniaca), and Almond Syrup. ISRN Toxicology. 2013; 610648:1-6. http://dx.doi.org/10.1155/2013/610648'.

4. Dicenta F, Martınez-Gomez P, Grane N, Martin ML, Leon A, Cánovas JA et al. Relationship between Cyanogenic Compounds in Kernels, Leaves, and Roots of Sweet and Bitter Kernelled Almonds. Journal of Agricultural and Food Chemistry. 2002; 50(7): 2149-2152.

5. EFSA CONTAM Panel (EFSA Panel on Contaminants in the Food Chain). Scientific opinion on the acute health risks related to the presence of cyanogenic glycosides in raw apricot kernels and products derived from raw apricot kernels. EFSA Journal 2016;14(4):4424, 47 pp. doi:10.2903/ j.efsa.2016.4424.

6. WHO. Cyanogenic glycosides (Who Food Additives Series30). 2012. http://www.inchem.org.

7. Potter D, Eriksson T, Evans RC, Oh S, Smedmark JEE, Morgan DR, et al. Phylogeny and classification of Rosaceae: Pl. Syst. Evol. 2007; 266: 5-43.

8. Liegner KB, Beck EM, Rosenberg A. Laetrile-induced agranulocytosis. JAMA. 1981; 246 (24): 2841-42.'

9. Agunbiade SO, Olankolun JO. Evaluation of some nutritional characterstics of the Indian almond (Prunus amygdalus) nut. Pak J Nutr. 2006; 5:316-18.

10. Puri A, Sahai R, Singh KL, Saxena RP, Tan don JS, Saxena KC. Immunostimulant activity of dry fruits and plant materials which are used in the Indian traditional medical system for mothers after child birth and invalids. J Ethanopharmacol. 2000; 71:89-92.

11. Pinelo M, Rubilar M, Sineiro J, Nunez MJ. Extraction of anti-oxidant phenolics from almond hulls (Prunus amygdlaus) and pine sawdust (Pinus pinaster). Food Chem. 2004; 85:267-73.

12. Bansal P, Sannd R, Srikanth N, Lavekar GS. Effect of a traditionally designed nutraceutical on the stress induced immunoglobulin changes at Antarctica. Afr J Biochem Res. 2009; 3:1084-88.'

13. Mandalari G, Neuno-palop C, Bigignano G, Wickham MSJ, Narbad A. Potential prebiotic properties of almond seeds. J. Applied and Environmental Microbiology. 2008; 74(14): 4264-70.

14. Berryman CE, Preston AG, Karmally W, Deckelbaum RJ, Kris-Either ton PM. Effects of almond consumption on the reduction of LDL-Cholesterol: a discussion of potential mechanismsand future research directions. J Nutr. Rev. 2011; 69:171-85.

15. Remelli W, Guerrieri N, Klodmann J, Papenbrock J, Pagani S, Forlani F. Involvement of the Azotobacter vinelandii rhodanese-like protein RhdA in the glutathione regeneration pathway.PLoS One. 2012;7(9):e45193.'

16. Al-qarawi A, Mousa HM, Ali BH. Tissue and intracellular distribution of rhodanese and mercaptopyruvate sulphotrans- ferases in ruminants and birds. Vet Res. 2001; 32:63-70. doi:10.1051/ vetres:2001110.'

17. Ehigie A. F., Okonji R.E, Abdulrasak M.A., Ehigie L.O. Partial Purification and Characterisation of Rhodanese from Zinginber officinale (Ginger). In: Olusola Ojurongbe (Ed), Translating Research Findings into Policy in Developing Countries Contributions from Humboldt Kolleg Osogbo-2017. Lap lambert Academic publishing. 2017a; pp 88-100.

18. Agboola FK, Okonji RE. Presence of Rhodanese in the Cytosolic Fraction of the Fruit Bat (Eidolon helvum) Liver. Journal of Biochemistry and Molecular Biology. 2004; 37(3): 275-281.

19. Bradford MM. A rapid and sensitive method for the quantitation of microgram quantities of protein utilizing the principle of protein-dye binding. Analytical Biochemistry. 1976; 72: 248-254.

20. Weber K, Osborn M. Protein and sodium dodecyl sulphate: Molecular weight determination on polyacrylamide gels and related procedures; in The Proteins, Neurath, H. and Hill, R. L. (eds.), Academic Press, New York, USA. 1975; pp. 179-223.

21. Sorbo BH. Rhodanese. Acta Chem. Scand 1953a; 7: 1137-1145.

22. Sorbo BH. Crystalline rhodanese (II). Enzyme catalyzed reaction. Acta Chem. Scand. 1953b; 7: 1137-1145.

23. Lee CH, Hwang JH, Lee YS, Cho KS. Purification and characterization of mouse liver rhodanese. J. Biochem. Mol. Biol. 1995; 28: 170-176.

24. WHO. Cyanide in Drinking-water Background document for development of WHO Guidelines for Drinking-water Quality. 2007

25. Ermans AM, Bourdoux P, Kintheart J, Lagasse R, Luvivila K, Mafuata M, Thilly cretinism. In: F. Delange, R. Ahluwalia (Eds.), Cassava toxicity and thyroid: C.M. and Delange, F. 1983. Role of cassava in the etiology of endemic goitre and Research Centre Research and public health issues, pp 9-16. Ottawa: International Development

26. JECFA. Cyanogenic glycosides. In: Toxicological evaluation of certain food additives and naturally occurring toxicants. Geneva, World Health 
Organization, 39th Meeting of the Joint FAO/WHO Expert Committee on Food Additives (WHO) Food Additives Series 30. 1993 http:// www.inchem.org/documents/jecfa/jecmono/v30je18.htm).

27. Doucleff M, Terry N. Pumping out the arsenic. Nat. Biotechnol. 2002; 20: 1094-1096.

28. Anosike EO, Ugochukwu EN. Characterization of Rhodanese from Cassava Leaves and Tubers. Journal of Experimental Botany. 1981; 32 (130) 1021-1027.

29. Chew MY, Boey CG. Rhodanese of tapiocal leaf. Phytochemistry. 1972; 11: $167-160$.

30. Tomati U, Federici G, Cannella C. Ferredoxin oxidation by cabbage leaf rhodanese. Phytochemistry (OXF). 1974; 13 (9): 1703-1706.

31. Ehigie LO, Okonji RE, Abdulrasak MA. kinetic and biochemical characterisation of rhodanese from seed, mesocarp and capsule of snake tomato (Trichosanthes cucumerina) fruit. Acta Velit. 2017b; 4 ( 3): 9-37

32. Hatzfeld Y, Saito K. Evidence for the existence of rhodanese (thiosulfate:cyanide sulfurtransferase) in plants: preliminary characterization of two rhodanese cDNAs from A rabidopsis thaliana. FEBS Lett. 2000; 470(2): 147-150

33. Ebizimor W. Effects of Temperature, $\mathrm{pH}$ and Some Monoatomic Sulphur Compounds on Rhodanese from Sheep Liver. Journal of Natural Sciences Research. 2015; 5(5):42-47.

34. Jack AS, Anosike EO, Brown H, Ben-Chioma A. Some Biochemical Properties Of Liver Rhodanese (E. C. 2. 8. 1.1) Isolated from a Typical Marine Fish (Lutjanus goreensis) . International Journal of Science and Research (IJSR). 2015; 4 (10): 1524-1530.

35. Westley J. Rhodanese and the sulphane pool. Enzymatic basis of detoxification. Academic Press Inc. 1980; 2:245-259

36. Ayinla ZA, Okonji RE, Fagbohunka BS, Ehigie LO, Ojo OO. Physicochemical properties of rhodanese: A cyanide detoxifying enzyme from Pentadiplandra brazzeana (Baill) root. African Journal of Biotechnology. 2017; 16 (14): 704 - 711
37. Okonji RE, James IE, Madu JO, Fagbohunka BS, Agboola FK. Purification and Characterization of Rhodanese from the Hepatopancreas of Garden Snail, Limicolaria flammea. Ife Journal of Science. 2015; 17(2):289-303.

38. Boey C, Yeoh H, Chew M. Purification of tapioca leaf rhodanese. Phytochemistry. 1976; 15: 1343-1344.

39. Ehigie OL, Okonji RE, Balogun RO, Bamitale KDS. Distribution of Enzymes (Rhodanese, 3-Mercaptopyruvate Sulphurtransferase, Arginase And Thiaminase) in Some Commonly Consumed Plant Tubers in Nigeria. Special Issue - 2nd International Conference on Engineering and Technology Research. 2013; 4(9):8-14.

40. Okonji R.E, Adewole HA, Kuku A, Agboola FK. Physicochemical Properties of Mudskipper (Periophthalmus Barbarus Pallas) Liver Rhodanese. Australian Journal of Basic and Applied Sciences. 2011; 5(8): 507-514.

41. Akinsiku OT, Agboola FK, Kuku A, Afolayan A. Physicochemical and kinetic characteristics of rhodanese from the liver of African catfish Clarias gariepinus Burchell in Asejire lake," Fish Physiology and Biochemistry. 2010; 36 (3): 573-586.

42. Ebizimor W. Effects of Temperature, $\mathrm{pH}$ and Some Monoatomic Sulphur Compounds on Rhodanese from Sheep Liver. Journal of Natural Sciences Research. 2015; 5(5):42-47.

43. Ulmer DD, Vallee B L. Role of metals in sulphurtransferase activity. Annual Review of Biochemistry. 1972; 32, 86-90.

44. Obasi UE, Abasi K, and Ilaya OB. A comparative analysis of rhodanese enzyme isolated from the seed and mesocarp of snake tomato (T. cucumerina)'. Advances in Agricultural Biotechnology. 2017; 1 (1): 1-7.

45. Ezzi MI, Pascual JA, Gould B J, Lynch JM. Characterisation of the rhodanese enzyme in Trichoderma spp. Enzyme Microbiol. Technol. 2003; 32(5): 629-634.

46. Jarabak R, Westley J. Human Liver Rhodanese: Nonlinear Kinetic Behaviour. Double Displacement Mechanism. Biochem. 1974; 13(16): 3233 3236 